\title{
Pengaruh motivasi dan semangat kerja terhadap kinerja pegawai pada kantor badan pengelola pajak dan retribusi daerah kabupaten kapuas
}

\author{
Adelia \\ Fakultas Ekonomi dan Bisnis, Universitas Palangka Raya \\ e-mail: Adelia151996@gmail.com
}

\begin{abstract}
Abstrak
Tujuan, - Tujuan penelitian ini adalah untuk memberikan penjelasan tentang pengaruh Motivasi dan Semangat Kerja terhadap kinerja pegawai pada kantor Badan Pengelola Pajak dan Retribusi Daerah Kabupaten Kapuas.

Desain/Methodologi/Pendekatan - Metode penelitian yang digunakan adalah pendekatan penelitian kuantitatif, data yang terkumpul dianalisis dengan menggunakan pendekatan eksplanotory dengan teknik sampling jenuh, software yang digunakan adalah SPSS 20.

Temuan penelitian - Hasil ini menunjukkan bahwa Motivasi dan Semangat Kerja berpengaruh positif dan signifikan terhadap kinerja pegawai.
\end{abstract}

Kata kunci: Motivasi, Semangat Kerja, Kinerja Pegawai

The Effect of Motivation and Work Spirit on Employee Performance at the Office of the Regional Tax and Retribution Management Agency of Kapuas Regency

\begin{abstract}
Purpose, - The purpose of this study was to provide an explanation of the effect of motivation and work spirit on employee performance at the Office of the Regional Tax and Retribution Management Agency of Kapuas Regency.

Design/methodology/approach - The research method used is a quantitative research approach, the data collected is analyzed using an explanatory approach with saturated sampling technique, the software used is SPSS 20.

Findings - These results indicate that motivation and work spirit have a positive and significant effect on employee performance.
\end{abstract}

Keywords: Motivation, Work Spirit, Employee Performance 


\section{PENDAHULUAN}

Peranan pegawai bagi organisasi sangat dominan, karena pegawai adalah penghasil kerja bagi organisasi. Hal ini berarti setiap pekerjaan dalam organisasi selalu dilaksanakan oleh pegawai. Berhasil tidaknya suatu organisasi ditentukan oleh unsur manusia yang melakukan pekerjaan sehingga perlu adanya balas jasa terhadap pegawai sesuai dengan sifat dan keadaanya.

Seorang pegawai perlu diperlakukan dengan baik agar pegawai tetap bersemangat dalam bekerja. Pimpinan organisasi dituntut untuk memperlakukan pegawai dengan baik dan memandang mereka sebagai manusia yang mempunyai kebutuhan baik materi maupun non materi. Pimpinan organisasi juga perlu mengetahui, menyadari dan berusaha memenuhi kebutuhan pegawainya sehingga pegawai dapat bekerja sesuai dengan harapan organisasi.

Motivasi merupakan suatu proses mempengaruhi atau mendorong seseorang atau kelompok orang agar mau melaksanakan usaha atau kerja sesuai yang telah ditetapkan organisasi. Motivasi berkaitan dengan alasan-alasan atau hal-hal yang telah mendorong atau menggerakkan seseorang untuk melakukan sesuatu. Motivasi dapat datang dari dalam maupun dari luar individu.

Semangat kerja pada hakekatnya adalah merupakan perwujudan dari pada moral kerja yang tinggi. Moral kerja yang tinggi merupakan semangat dan kegairahan kerja. Semangat kerja menggambarkan suatu perasaan dan menunjukkan iklim serta suasana pekerjaan.

Kinerja merupakan perilaku nyata yang di tampilkan setiap orang sebagai prestasi kerja yang di hasilkan oleh pegawai sesuai dengan perananannya dalam organisasi. Sehingga dalam hal ini kinerja pegawai merupakan suatu hal yang sangat penting dalam upaya organisasi atau perusahaan untuk mencapai tujuannya. Faktor motivasi memiliki hubungan langsung dengan kinerja individual pegawai.

Badan Pengelola Pajak dan Retribusi Daerah (BPPRD) Kabupaten Kapuas yang berlokasi di Jalan Tambun Bungai No. 43 Kuala Kapuas, sebagai salah satu perangkat daerah yang dibentuk berdasarkan Peraturan Daerah Nomor 10 tahun 2016 tentang Pembentukan Susunan Perangkat Daerah Peraturan BupatiKapuas Nomor 65 tahun 2016 tentang Kedudukan, Susunan Organisasi, Tugas dan Fungsi Serta Tata Kerja Badan Pengelola Pajak dan Retribusi Daerah Kabupaten Kapuas yang diserahi tugas untuk mengelola pajak dan retribusi daerah yang menjadi kewenangan daerah.

Permasalahan hasil observasi atau penelitian ini adalah kurangnya motivasi dan semangat kerja pegawai kantor BPPRD, di karenakan pemimpin kurang mampu memberikan perhatian kepada bawahan seperti memberikan penghargaan atau insentif kepada pegawai atas pekerjaan yang telah di lakukannya selama ini. Dari fenomena-fenomena yang telah ditemukan ini, maka penulis tertarik melakukan suatu penilitan, dan memilih judul " Pengaruh Motivasi dan Semangat Kerja terhadap Kinerja Pegawai pada Kantor Badan Pengelola Pajak dan Retribusi Daerah Kabupaten Kapuas.”

\section{Kajian Pustaka \\ Motivasi}

Menurut Samsudin (2010) motivasi adalah proses mempengaruhi atau mendorong dari luar terhadap seseorang atau kelompok kerja agar mereka mau melaksanakan sesuatu yang telah ditetapkan. Menurut Winardi (2016) motivasi merupakan suatu kekuatan potensial yang ada di dalam diri seorang manusia, yang dapat dikembangkannya sendiri atau dikembangkan oleh sejumlah kekuatan luar yang pada intinya berkisar sekitar imbalan moneter dan imbalan 
non moneter, yang dapat mempengaruhi hasil kinerjanya secara positif atau negatif. Menurut Malayu (2015) motivasi adalah mempersoalkan bagaimana cara mendorong gairah kerja bawahan, agar mereka mau bekerja keras dengan memberikan semua kemampuan dan keterampilan untuk mewujudkan tujuan perusahaan.

\section{Semangat Kerja}

Menurut Nitisemito yang dikutip kembali oleh Darmawan (2013) semangat kerja dapat diartikan juga sebagai suatu iklim atau suasana kerja yang terdapat di dalam suatu organisasi yang menunjukkan rasa kegairahan di dalam melaksanakan pekerjaan dan mendorong mereka untuk bekerja secara lebih baik dan lebih produktif. Menurut Sri Widodo (2015) Semangat kerja adalah mencerminkan kondisi karyawan dalam lingkungan kerjanya, bila semangat kerja baik maka perusahaan memperoleh keuntungan, seperti rendahnya tingkat absensi, kecilnya keluar masuk karyawan dan meningkatkan produktivitas tenaga kerja. Menurut Hasibuan (2014) semangat kerja adalah keinginan, kesungguhan seseorang mengerjakan pekerjaannya dengan baik, berdisiplin untuk mencapai prestasi kerja yang maksimal, kemauan, dan kesenangan yang mendalam terhadap pekerjaan yang dilakukan.

\section{Kinerja Pegawai}

Menurut Wirawan dalam Abdullah (2014) kinerja adalah keluaran yang dihasilkan oleh fungsi-fungsi atau indikator-indikator suatu pekerjaan atau suatu profesi dalam waktu tertentu. Menurut Amstrong dan Baron dalam Abdullah (2014) menjelaskan, kinerja merupakan hasil pekerjaan yang mempunyai hubungan kuat dengan tujuan strategi organisasi, kepuasan konsumen dan memberikan kontribusi ekonomi. Menurut Priansa (2017) kinerja dalam bahasa Inggris disebut dengan job performance atau actual performance atau level of performance, yang merupakan tingkat keberhasilan pegawai dalam menyelesaikan pekerjaannya.

Berdasarkan permasalahan yang ada dan dari tinjauan teoritistentang variabel Motivasi, Semangat Kerja dan Kinerja Karyawan maka hipotesis yang diajukan sebagai berikut :

Hipotesis 1 : Diduga motivasi secara parsial berpengaruh terhadap kinerja pegawai

Hipotesis 2 : Diduga semangat kerja secara parsial berpengaruh terhadap kinerja pegawai.

Hipotesis 3 : Diduga motivasi dan semangat kerja secara simultan berpengaruh terhadap kinerja pegawai.

Berdasarkan tinjauan pustaka, maka disusunlah kerangka berpikir sebagai sebuah model penelitian untuk menjelaskan bagaimana kinerja pegawai ditentukan oleh pengaruh Motivasi dan Semangat Kerja seperti pada gambar berikut:

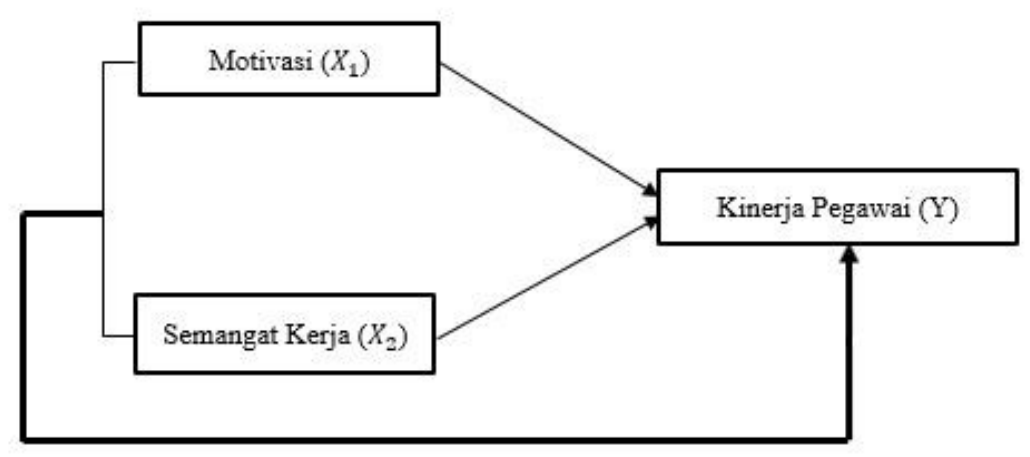

Gambar 1. Kerangka Konseptual Penelitian 


\section{METODE PENELITIAN}

Pendekatan yang digunakan dalam penelitian ini adalah pendekatan kuantitatif. Pendekatan kuantitatif merupakan pendekatan penelitian yang bekerja dengan angka, datanya berwujud bilangan, dianalisisis menggunakan statistik untuk menjawab pertanyaan atau terhadap hipotesis penelitian yang bersifat spesifik dan untuk melakukan prediksi bahwa suatu variabel tertentu mempengaruhi variabel yang lainnya. Populasi dalam penelitian ini adalah seluruh pegawai yang bekerja pada Kantor Badan Pengelola Pajak dan Retribusi Daerah Kabupaten Kapuas, yaitu sebanyak 35 Orang Pegawai. Sampel merupakan subset dari sebuah populasi, terdiri dari beberapa anggota populasi. Teknik pengambilan sampel yang akan digunakan dalam penelitian ini adalah sampling jenuh, yaitu teknik pengambilan sampel apabila semua populasi digunakan sebagai sampel dan dikenal juga dengan istilah sensus (Sugiyono, 2014).

Jenis penelitian ini termasuk dalam kategori penelitian explanatory.Menurut Singarimbun (2012) explanatory research adalah penelitian yang digunakan untuk menjelaskan hubungan kausal antara variabel-variabel melalui pengujian hipotesa yang dirumuskan atau sering kali disebut sebagai penelitian penjelas. Penelitian ini memiliki tingkat yang tinggi karena tidak hanya mempunyai nilai mandiri maupun membandingkan tetapi juga berfungsi untuk menjelaskan, meramalkan, dan juga mengontrol suatu gejala dengan pendekatan kuantitatif. Pada penelitian ini skala Likert digunakan untuk mengetahui bagaimana sikap, pendapat, dan persepsi responden tehadap vaiabel Motivasi dan Semangat Kerja terhadap Kinerja pegawai pada Kantor Badan Pengelola Pajak dan Retribusi Daerah Kabupaten Kapuas.

\section{Pengukuran}

Motivasi menurut Teori Maslow (1943-1970) motivasi di diukur dari 5 indikator, yaitu : 1) Kebutuhan Fisiologis, 2) Kebutuhan Rasa Aman, 3) Kebutuhan Sosial, 4) Kebutuhan Pengakuan, 5) Kebutuhan Aktualisasi Diri. Responden menilai semua item dengan skala Likert 5 poin $(1=$ sangat tidak setuju; $5=$ sangat setuju $)$.

Semangat Kerja menurut Menurut Zainun (1991) kinerja karyawan memiliki 6 indikator,6 Indikator tersebut antara lain adalah : 1) Hubungan yang harmonis antara pimpinan dengan bawahan terutama antara pimpinan kerja sehari-hari langsung berhubungan dan berhadapan dengan para bawahan, 2) Kepuasan para petugas terhadap tugas dan pekerjaannya karena memperoleh tugas yang disukai sepenuhnya, 3) Terdapat satu suasana dan iklim kerja yang yang bersahabat dengan anggota organisasi, apabila dengan mereka yang sehari-hari banyak berhubungan dengan pekerjaan, 4) Rasa pemanfaatan bagi tercapainya tujuan organisasi yang juga merupakan tujuan bersama mereka yang harus diwujudkan secara bersama-sama pula, 5) Adanya tingkat kepuasan ekonomis dan kepuasan nilai lainnya yang memadai sebagai imbalan yang dirasakan adil terhadap jarih payah yang telah diberikan kepada organisasi, 6) Adanya ketenangan jiwa, jaminan kepastian serta perlindungan terhadap segala sesuatu yang dapat membahayakan diri pribadi dan karier dalam perjalanan. Responden menilai semua item denganskala Likert 5poin ( $1=$ sangat tidak setuju; $5=$ sangat setuju).

Kinerja Menurut Robbins (2006) kinerja memiliki enam indikator, yaitu: 1) Kualitas, 2) Kuantitas, 3) Ketepatan Waktu, 4) Efektivitas, 5) Kemandirian, 6) Komitmen kerja.

Responden menilai semua item denganskala Likert 5poin (1= sangat tidak setuju; $5=$ sangat setuju). 
Semangat Kerja Responden menilai semua item dengan skala Likert 5 poin $(1=$ sangat tidak setuju; 5 = sangat setuju).Indikator untuk mengukur kinerja pekerjaan, 1) Jumlah pekerjaan, 2) Kualitas pekerjaan, 3) Ketepatan waktu, 4) Kehadiran, 5) Kemampuan Kerjasama.

\section{HASIL DAN PEMBAHASAN}

Penelitian dilakukan pada Kantor Badan Pengelola Pajak dan Retribusi Daerah Kabupaten Kapuas, variabel bebas (independent variabel) adalah Motivasi (X1) dan Semangat kerja (X2) sedangkan variabel yang terikat (dependent variabel) adalah kinerja (Y), dapat di lihat pada tabel Deskritif Statistik berikut ini:

Tabel 1. Motivasi (X1)

\begin{tabular}{|c|c|c|c|c|c|c|c|c|}
\hline \multirow{3}{*}{$\begin{array}{l}\text { Indikator/ } \\
\text { Item }\end{array}$} & \multicolumn{5}{|c|}{ Skor Jawaban } & \multirow[t]{3}{*}{$\mathbf{n}$} & \multirow{2}{*}{\multicolumn{2}{|c|}{ Mean }} \\
\hline & 1 & 2 & 3 & 4 & 5 & & & \\
\hline & $\mathrm{f}$ & $\mathrm{f}$ & $\mathrm{f}$ & $\mathrm{f}$ & $\mathrm{f}$ & & Item & Variable \\
\hline $\mathrm{X} 1.1$ & 0 & 1 & 14 & 16 & 4 & 35 & 3,66 & \multirow{6}{*}{3,62} \\
\hline $\mathrm{X} 1.2$ & 0 & 0 & 4 & 30 & 1 & 35 & 3,91 & \\
\hline $\mathrm{X} 1.3$ & 0 & 2 & 17 & 13 & 3 & 35 & 3,49 & \\
\hline $\mathrm{X} 1.4$ & 0 & 2 & 17 & 14 & 2 & 35 & 3,46 & \\
\hline$X 1.5$ & 0 & 0 & 16 & 17 & 2 & 35 & 3,60 & \\
\hline X1.6 & 0 & 2 & 10 & 21 & 2 & 35 & 3,66 & \\
\hline
\end{tabular}

Sumber: Data primer diolah tahun 2021

Berdasarkan tabel diatas tampak bahwa mean (rata-rata) jawaban responden adalah 3,62 hal ini menunjukan bahwa responden menyatakan setuju tentang Indikator-indikator Motivasi kerja yang didapatkan selama ini dapat meningkatkan kinerja Pegawai Kantor Badan Pengelola Pajak dan Retribusi Daerah Kabupaten Kapuas.

Tabel 2. Semangat Kerja (X2)

\begin{tabular}{|c|c|c|c|c|c|c|c|c|}
\hline \multirow{3}{*}{$\begin{array}{l}\text { Indikator/ } \\
\text { Item }\end{array}$} & \multicolumn{5}{|c|}{ Skor Jawaban } & \multirow[t]{3}{*}{$\mathbf{n}$} & \multirow{2}{*}{\multicolumn{2}{|c|}{ Mean }} \\
\hline & 1 & 2 & 3 & 4 & 5 & & & \\
\hline & f & $\mathrm{F}$ & f & f & $f$ & & Item & Variable \\
\hline X2.1 & 0 & 0 & 7 & 26 & 2 & 35 & 3,86 & \multirow{6}{*}{3,77} \\
\hline $\mathrm{X} 2.2$ & 0 & 0 & 11 & 22 & 2 & 35 & 3,74 & \\
\hline X2.3 & 0 & 2 & 10 & 22 & 1 & 35 & 3,63 & \\
\hline X2.4 & 0 & 0 & 8 & 27 & 0 & 35 & 3,77 & \\
\hline$X 2.5$ & 0 & 0 & 4 & 31 & 0 & 35 & 3,89 & \\
\hline X2.6 & 0 & 2 & 17 & 15 & 1 & 35 & 3,43 & \\
\hline
\end{tabular}

Sumber: Data primer diolah Tahun 2021 
Berdasarkan tabel diatas tampak bahwa mean (rata-rata) jawaban responden adalah 3,77 hal ini menunjukan bahwa responden menyatakan setuju tentang Indikator-indikator Semangat kerja yang didapatkan selama ini dapat meningkatkan kinerja Pegawai Kantor Badan Pengelola Pajak dan Retribusi Daerah Kabupaten Kapuas.

Tabel 3. Kinerja (Y)

\begin{tabular}{|c|c|c|c|c|c|c|c|c|}
\hline \multirow{3}{*}{$\begin{array}{c}\text { Indikator/ } \\
\text { Item }\end{array}$} & \multicolumn{5}{|c|}{ Skor Jawaban } & \multirow{3}{*}{$\mathbf{n}$} & \multirow{2}{*}{\multicolumn{2}{|c|}{ Mean }} \\
\hline & \multirow[b]{2}{*}{$\mathrm{f}$} & \multirow{2}{*}{$\frac{2}{F}$} & \multirow{2}{*}{$\frac{3}{\mathrm{f}}$} & \multirow{2}{*}{$\frac{4}{\mathrm{f}}$} & \multirow{2}{*}{$\begin{array}{l}5 \\
f\end{array}$} & & & \\
\hline & & & & & & & Item & Variable \\
\hline Y1 & 0 & 2 & 17 & 14 & 2 & 35 & 3,46 & \multirow{6}{*}{3,66} \\
\hline Y2 & 0 & 0 & 15 & 19 & 1 & 35 & 3,60 & \\
\hline Y3 & 0 & 0 & 11 & 21 & 3 & 35 & 3,77 & \\
\hline Y4 & 0 & 0 & 11 & 22 & 2 & 35 & 3,74 & \\
\hline Y5 & 0 & 0 & 8 & 27 & 0 & 35 & 3,77 & \\
\hline Y6 & 0 & 0 & 12 & 21 & 2 & 35 & 3,71 & \\
\hline
\end{tabular}

Sumber: Data Primer diolah Tahun 2021

Berdasarkan tabel diatas tampak bahwa mean (rata-rata) jawaban responden adalah 3,66 hal ini menunjukan bahwa responden menyatakan setuju tentang Indikator-indikator Kinerja Pegawai Kantor Badan Pengelola Pajak dan Retribusi Daerah Kabupaten Kapuas.

\section{Menentukan Model Regresi Linear Berganda} Persamaan Regresi Berganda

Tabel 4. Hasil Persamaan Regresi Linear Berganda

\begin{tabular}{|c|c|c|c|c|c|c|}
\hline \multirow[t]{2}{*}{ Model } & & \multicolumn{2}{|c|}{ Unstandardized Coefficients } & \multirow{2}{*}{$\begin{array}{l}\text { Standardized } \\
\text { Coefficients } \\
\text { Beta }\end{array}$} & \multirow[t]{2}{*}{$\mathrm{t}$} & \multirow[t]{2}{*}{ Sig. } \\
\hline & & $\mathrm{B}$ & Std. Error & & & \\
\hline \multirow{3}{*}{1} & (Constant) & 2,909 & 2,448 & & 1,188 & ,243 \\
\hline & Motivasi (X1) & ,421 & 132 & ,506 & 3,180 & ,003 \\
\hline & Semangat Kerja (X2) & ,447 & 184 & ,387 & 2,429 &, 021 \\
\hline
\end{tabular}

a. Dependent Variable: Kinerja (Y)

Berdasarkan tabel diatas dapat ditentukan model regresi linear berganda yang dinyatakan dalam bentuk persamaan sebagai berikut:

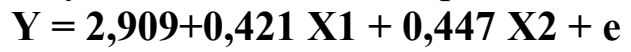

Dari nilai persamaan regresi diatas dapat diketahui bahwa:

1. Konstanta sebesar 2,90 artinya jika variabel Motivasi dan Semangat kerja konstan atau tetap, maka nilai kinerja pegawai adalah 2,90 atau bila dipersentasikan sebesar 29\%.

2. Nilai Koefisien Regresi untuk variabel Motivasi pada persamaan regresi menunjukkan nilai positif sebesar 0,421, artinya jika Motivasi meningkat sebesar 1 satuan maka nilai 


\section{Uji Hipotesis}

kinerja pegawai akan meningkat 0,421 dengan kata lain, besarnya pengaruh Motivasi terhadap Kinerja pegawai adalah 0,421 atau $42,1 \%$.

3. Nilai Koefisien Regresi untuk variabel Semangat kerja pada persamaan regresi menunjukkan nilai positif sebesar 0,447, artinya jika Semangat kerja meningkat sebesar 1 satuan maka nilai kinerja pegawai akan meningkat 0,447 dengan kata lain, besarnya pengaruh Semangat kerja terhadap Kinerja pegawai adalah 0,447 atau 44,7\%

\section{Uji t (Parsial)}

\begin{tabular}{llcc}
\multicolumn{4}{c}{ Tabel 5. Hasil Uji Parsial (t) } \\
\hline Model & & $\mathrm{t}$ & Sig. \\
& & & \\
& & & \\
& & & \\
1 & Constant) & 3,188 &, 243 \\
& Motivasi (X1) & 3,180 &, 003 \\
& Semangat Kerja (X2) & 2,429 &, 021 \\
\hline
\end{tabular}

Koefisien dari variabel Motivasi (X1) adalah signifikan pada $\alpha=0,05$, karena thitung $>\mathrm{t}$ tabel $(3,180>2,063)$ atau nilai sig. $0.003<0,05$. Artinya pengaruh variabel Motivasi terhadap Kinerja pegawai adalah signifikan. Berarti hipotesis yang menyatakan bahwa Motivasi berpengaruh terhadap Kinerja pegawai bisa diterima.

Koefisien dari Semangat kerja (X2) adalah signifikan pada $\alpha=0,05$, karena $t$ hitung $>$ $\mathrm{t}$ tabel $(2,429>2,063)$ atau nilai sig. $0.021<0,05$. Artinya pengaruh variabel Semangat kerja terhadap Kinerja pegawai adalah signifikan. Berarti hipotesis yang menyatakan bahwa Semangat kerja berpengaruh terhadap Kinerja pegawai bisa diterima.

\section{Uji F (Simultan)}

\section{Tabel 6. Hasil Uji Simultan (F)}

\begin{tabular}{|c|c|c|c|c|c|c|}
\hline Model & & Sum of Squares & Df & Mean Square & $\mathrm{F}$ & Sig. \\
\hline \multirow{3}{*}{1} & Regression & 127,327 & 2 & 63,664 & 41,954 &, $000^{\mathrm{b}}$ \\
\hline & Residual & 48,559 & 32 & 1,517 & & \\
\hline & Total & 175,886 & 34 & & & \\
\hline
\end{tabular}

Uji ini digunakan dengan tujuan untuk membuktikan apakah variabel bebas berpengaruh secara bersama-sama terhadap variabel terikat. Dari hasil perhitungan melalui SPSS menunjukkan $\mathrm{F}_{\text {hitung }}$ sebesar 41,954 dan $\mathrm{F}_{\text {tabel }}=3,29$ (dengan menggunakan tingkat signifikasi $0,00 \%$ serta derajat kebebasan $(\mathrm{df}) ; \mathrm{n}-(\mathrm{k}+1) ; 35-(2+1)=32$. ini menyatakan bahwa $\mathrm{F}_{\text {hitung }}(41,954)>(3,29) \quad \mathrm{F}_{\text {tabel }}$ sehingga hipotesis diterima. Artinya bahwa variabel bebas yang terdiri dari Motivas (X1) dan Semangat Kerja (X2) secara simultan berpengaruh terhadap kinerja Pegawai Kantor Badan Pengelola Pajak dan Retribusi Daerah Kabupaten Kapuas. 
Tabel 7. Koefisien Determinasi $\mathbf{R}^{2}$

Model Summary ${ }^{\mathbf{b}}$

\begin{tabular}{|l|l|l|l|l|}
\hline Model & R & R Square & Adjusted R Square & Std. Error of the Estimate \\
\hline 1 &, $851^{\mathrm{a}}$ &, 724 &, 707 & 1,23185 \\
\hline
\end{tabular}

a. Predictors: (Constant), Semangat Kerja (X2), Motivasi (X1)

b. Dependent Variable: Kinerja (Y)

Nilai koefisien determinasi (R2) sebesar 0,724 menunjukkan bahwa variasi kinerja pegawai dijelaskan oleh variabel Motivasi (X1) dan Semangat Kerja (X2) sebesar 72,4\% sementara $27,6 \%$ dijelaskan oleh variabel lain yang tidak dianalisis dalam model.

\section{Pembahasan}

Berdasarkan hasil analisis seacara parsial, diperoleh bahwa koefisien $\beta$ dari Motivasi (X1) adalah positif, tanda positif menunjukkan bahwa hubungan antara variabel Motivasi (X1) dengan variabel Kinerja Pegawai (Y) adalah searah, artinya bahwa semakin tinggi Motivasi seorang pegawai maka akan semakin tinggi pula kinerja yang dimilikinya. Setelah dilakukan pengujian maka ternyata bahwa nilai sig adalah signifikan, dengan demikian berarti bahwa terdapat pengaruh yang signifikan antara Motivasi (X1) terhadap Kinerja Pegawai (Y).

Berdasarkan hasil analisis seacara parsial, diperoleh bahwa koefisien $\beta$ dari Semangat Kerja (X2) adalah positif, tanda positif menunjukkan bahwa hubungan antara variabel Semangat Kerja (X2) dengan variabel Kinerja Pegawai (Y) adalah searah, artinya bahwa semakin tinggi Semangat kerja seorang pegawai maka akan semakin tinggi pula kinerja yang dimilikinya. Setelah dilakukan pengujian maka ternyata bahwa nilai sig adalah signifikan, dengan demikian berarti bahwa terdapat pengaruh yang signifikan antara Semangat Kerja (X2) terhadap Kinerja Pegawai (Y).

Berdasarkan hasil analisis secara simultan, diperoleh bahwa Motivasi (X1) dan Semangat Kerja (X2) adalah positif, tanda positif menunjukkan bahwa hubungan antara variabel Motivasi (X1) dan Semangat Kerja (X2) dengan variabel Kinerja Pegawai (Y) adalah searah, artinya bahwa semakin tinggi Motivasi (X1) dan Semangat Kerja (X2) seorang Pegawai maka akan semakin tinggi pula kinerja yang dimilikinya.

\section{SIMPULAN}

Berdasarkan hasil analisis dan pembahasan tentang Motivasi dan Semangat kerja terhadap Kinerja Pegawai Kantor Badan Pengelola Pajak dan Retribusi Daerah Kabupaten Kapuas maka dapat ditarik kesimpulan sebagai berikut Motivasi Kerja (X1) berpengaruh Secara Parsial terhadap Kinerja Pegawai Kantor Badan Pengelola Pajak dan Retribusi Daerah Kabupaten Kapuas, Semangat Kerja (X2) berpengaruh Secara Parsial Kantor Badan Pengelola Pajak dan Retribusi Daerah Kabupaten Kapuas, Motivasi (X1) dan Semangat Kerja (X2) berpengaruh secara simultan terhadap Kinerja Pegawai Kantor Badan Pengelola Pajak dan Retribusi Daerah Kabupaten Kapuas. Penelitian ini telah diusahakan dan dilaksanakan sesuai dengan prosedur ilmiah, namun demikian masih memiliki keterbatasan,seperti sampel yang digunakan terbatas pada satu organisasi pemerintahan, sehingga belum memberikan hasil yang dapat digeneralisasikan pada seluruh organisasi pemerintahan. Bagi peneliti 
selanjutnya dapat memanfaatkan dan mengembangkan hasil penelitian ini dengan menggunakan variabel-variabel yang berbeda atau indikator-indikator yang digunakan masing-masing variabel perlu dikembangkan.

\section{REFERENSI}

Armstrong dan Baron dalam Irham Fahmi. 2012. Manajemen Kinerja. Jakarta.

Arikunto, s. 2002. Metodologi Penelitian Suatu Pendekatan Proposal. Jakarta: PT. Rinekae Cipta

Bovita, Aswin. 2014. Pengaruh Motivasi dan Semangat Kerja terhadap Kinerja Karyawan Pegawai Dinas Perkebunan Kabupaten Indragiri Hilir. Skripsi, thesis, Universitas Terbuka Jakarta

Ghozali, Imam. 2011. Aplikasi Analisis Multivariat Dengan Program SPSS. Universitas Diponegoro, Semarang.

Ghozali, Imam. 2013. Aplikasi Analisis Multivariat dengan Program IBM SPSS. Edisi 7. Semarang: Penerbit Universitas Diponegoro.

Hasibuan, Melayu SP. 2001. Organisasi dan Motivasi Dasar Peningkatan Produktivitas. Jakarta: Bumi Aksara

Hasibuan, Malayu. 2005. Organisasi dan Motivasi. PT. Bumi Aksara. Jakarta.

Hernowo. 2013. Pengaruh Motivasi Disiplin Dan Semangat Kerja Terhadap Kinerja Karyawan Outlet Distro Planet Di Kota Wonosobo. Skripsi thesis, Universitas Muhammadiyah Surakarta.

Mangkunegara, A. A. Anwar Prabu. 2004. Manajemen Sumber Daya Manusia. Bandung: PT. Remaja Rosda Karya.

Mangkunegara, Tb. Sjafri. 2009. Horison Bisnis, Manajemen, dan Sumber Manusia. Bogor: ITB Press.

Nitisemito, A.S. 1983. Manajemen Personalia.Ghalia Indonesia. Jakarta.

Notoadmojo, Soekidjo. 2009. Pengembangan Sumber Daya Manusia. Jakarta: Rineka Cipta.

Praptiwi, Ananti Wahyu Ajeng. 2017. Pengaruh Budaya Organisasi Terhadap Semangat Kerja Pada Karyawan Bagian Kantor PT Kereta Api Indonesia Daerah Operasi (DAOP) 5 Purwokerto. Skripsi thesis, Universitas Muhammadiyah Purwokerto.

Rivai, Veithzal. 2004. Kepemimpinan dan Perilaku Organisasi. PT Raja Grafindo Persada. Jakarta.

Rivai (2009). Manajemen Sumber Daya Manusia, Jakarta cetakan kesembilan.

Simamora, Henry. 2006. Manajemen Sumber Daya Manusia. STIE YPKN. Yogyakarta.

Sugiyono. 2005. Metode Penelitian Administrasi. Alfabeta. Bandung.

Sugiyono. 2011. Metode Penelitian Kuantitatif Kualitatif dan R\&D. Bandung: Alfabeta.

Sumantri, B. 2017. Pengaruh Kemampuan, Motivasi dan Semangat Kerja Terhadap Kinerja Guru SMP Negeri di Balongpanggang. e-Jurnal Mitra Pendidikan, 1(7), 789-800.

Sutrisno, E. 2009.Manajemen Sumber Daya Manusia. Edisi Ke-1. Prenada Media. Jakarta.

Sutrisno, E. 2010. Manajemen Sumber Daya Manusia. Jakarta: Kencana Prenada Media Group. 2014

Wibowo. 2011. Manajemen Kinerja. Jakarta: PT. Raja Grafindo Persada.

Widodo, Joko. 2007. Analisis Kebijakan Publik: Konsep dan Aplikasi Analisis Proses Kebijakan Publik. Malang: Bayumedia Publishing.

Winardi. 1992. Manajemen Perilaku Organisasi. PT. Citra Aditya Bakti. Bandung. 